\title{
FASILITAS PERANAN SARANA DAN PRASARANA TERHADAP PRODUKTIVITAS KERJA UKM DI KOTA MAGELANG
}

\author{
THE EFFECTS OF FACILITIES AND INFRASTRUCTURES \\ TOWARD THE PRODUCTIVITY OF SME'S WORK IN MAGELANG CITY
}

\author{
Harsono \\ Badan Penelitian dan Pengembangan Provinsi Jawa Tengah \\ Jalan Imam Bonjol No. 190, Semarang \\ E-mail: sekretariat@balitbangjateng.go.id
}

Diterima: 2 November 2012; direvisi: 29 November 2012; disetujui: 10 Desember 2012

\begin{abstract}
Abstrak
Permasalahan yang diangkat adalah bagaimana keadaan kualitas prasarana. Seberapa besar tingkat pengaruh antara variabel independen (promosi, pelatihan dan bantuan alat) dengan variabel dependen produktivitas kerja. Tujuan penelitian ini adalah untuk mengetahui gambaran tentang kualitas sarana dan prasarana UKM dan tingkat pengaruh antara variabel independen dengan variabel dependen. Manfaat yang diharapkan adalah hasil penelitian ini dapat menjadi bahan masukkan pengambilan kebijakan. Lokasi penelitian dilakukan di Kota Magelang. Metode penelitian yang digunakan populasi sebanyak 240 KUB dan ukuran sampel yang digunakan sebagai responden dalam penelitian ini berjumlah 40 orang. Untuk menentukan sampel tersebut digunakan simple random sampling. Analisis data dengan model statistik inferensial. Hasil yang didapat, karena F hitung > F tabel ( 16,078 >2,87 maka Ho ditolak, $\mathrm{H}$ altf. diterima artinya ada pengaruh secara signifikan antara promosi, pelatihan dan bantuan alat secara bersamasama terhadap produktivitas kerja. Pengembangan Sumber Daya Manusia (SDM) Peningkatan kualitas SDM dilakukan melalui berbagai cara seperti pendidikan dan pelatihan, seminar dan lokakarya, on the job training, pemagangan dan kerja sama usaha.
\end{abstract}

Kata kunci: sarana, prasarana, produktivitas, UKM.

\begin{abstract}
Issues raised is how the quality of infrastructure. What degree of influence of the independent variables (promotion, training and equipment) with the dependent variable labor productivity. The purpose of this study was to determine the picture quality of the facilities and infrastructure of SMEs and the level of influence between the independent variables with the dependent variable. The expected benefits are the results of this study may be material to enter policy making. The research location in Magelang. The method used a population of $240 \mathrm{KUB}$ and the sample size used as respondents in this study of 40 people. To determine the sample used simple random sampling. Analysis of the data with a model of inferential statistics. The results, as F count $>F$ table (16.078> 2.87 then the Ho is rejected, H altf. Acceptable means there is significant influence between promotion, training and support tools together to work productivity. Development of Human Resources (HR ) Improving the quality of human resources through various means such as education and training, seminars and workshops, on the job training, apprenticeships, and cooperative effort.
\end{abstract}

Keywords: facilities, infrastructure, productivity, SMEs.

\section{PENDAHULUAN}

Klaster makanan ringan di Kota Magelang, meliputi: usaha aneka makanan ringan Karya Boga beranggotakan 19 UKM, makanan ringan Jaya Abadi beranggotakan $18 \mathrm{UKM}$, aneka roti Karya Abadi beranggotakan 20 UKM, aneka roti Arsya Boga beranggotakan 40 UKM, aneka roti Mulya Boga beranggotakan 20 UKM, dan krupuk rambak 5 UKM. Di samping itu, masih terdapat berbagai jenis UKM yang masih dalam komunitas sentra.

Klaster makanan ringan di Kota Magelang memproduksi jenis makanan ringan atau kudapan (Inggris: snack), yakni istilah bagi makanan yang bukan sebagai makanan utama (makan pagi, makan siang atau makan malam). Makanan ringan berfungsi sebagai penghilang rasa lapar seseorang untuk sementara waktu, guna memberikan sedikit energi tubuh, atau sebagai makanan untuk dinikmati rasanya (http://id.id.facebook.com/pages/Makanan-ringan/ 11277179206995). Permasalahan: Bagaimana keadaan kualitas sarana dan prasarana, dan tingkat pengaruh antara variabel independen dengan variabel dependen.

Tujuan penelitian ini untuk mengetahui gambaran tentang kualitas sarana dan prasarana, dan mengetahui tingkat pengaruh antara variabel independen dengan variabel dependen. Manfaat yang bisa didapat dari penelitian ini adalah menjadi bahan 
masukkan pengambilan kebijakan di bidang Usaha Kecil Menengah makanan ringan di Kota Magelang.

Kondisi lingkungan saat ini ditandai dengan perubahan besar yang saling terkait serta membentuk lingkungan usaha yang semakin kompetitif. Ketiga hal tersebut adalah isu globalisasi, masalah-masalah nasional dan masalah-masalah lokal yang mendesak untuk disikapi oleh Birokrasi dengan penanganan yang integratif (Prof. Bhenyamin Hoessein). Sistem pelayanan publik juga akhirnya tidak bisa dipandang hanya sebagai penyelesaian permasalahan lokal, akan tetapi terkait juga dengan masalah-masalah globalisasi serta masalah nasional pada umumnya.

Perkembangan tersebut akan semakin meningkatkan daya kritis masyarakat dalam memandang dan menilai kinerja birokrasi. Usaha Kecil sebagaimana dimaksud Undang-Undang No. 9 Tahun 1995 adalah usaha produktif yang berskala kecil dan memenuhi kriteria kekayaan bersih paling banyak Rp 200.000.000,00 (dua ratus juta rupiah).

Jadi klaster adalah penggabungan beberapa aliansi dari beberapa perusahaan dalam suatu wilayah yang berdekatan. Adapun pengertian klaster, menurut Porter, 1998 adalah: "Klaster merupakan jaringan perusahaan-perusahaan yang terkonsentrasi secara geografis, yang dikhususkan kepada para pemasok, penyedia jasa-layanan, perusahaan yang terkait secara industri, dan lembaga asosiasi di daerah tertentu yang saling bersaing, namun juga saling bekerjasama." Menurut Mathis (2002), pelatihan adalah suatu proses dimana orang-orang mencapai kemampuan tertentu untuk membantu mencapai tujuan organisasi. Oleh karena itu, proses ini terikat dengan berbagai tujuan organisasi, pelatihan dapat dipandang secara sempit maupun luas. Secara terbatas, pelatihan menyediakan para pegawai dengan pengetahuan yang spesifik dan dapat diketahui serta keterampilan yang digunakan dalam pekerjaan mereka saat ini.

\section{METODE PENELITIAN}

Lokasi penelitian ini ditentukan dilakukan di Kota Magelang. Jenis data yang digunakan terdiri dari data primer dari hasil wawancara dengan responden UKM. Sedangkan data skunder dari Kota Dalam Angka tahun 2012.

Alat pengumpulan data menggunakan daftar wawancara dan kuestioner yang dilakukan pada populasi 240 orang, sample 40 orang. Sedangkan teknik analisis data yang digunakan adalah menggunakan program SPSS 16.

\section{HASIL DAN PEMBAHASAN}

Kelompok usaha survei yang dilakukan di lakukan di Kota Magelang ini meliputi tiga besar kelompok industri pengolahan makanan yang berjumlah 240 unit usaha. Sarana dan prasarana UKM Sarana dan prasarana yang meliputi lahan dan bangunan, jalan raya, listrik, air, telekomunikasi merupakan faktor penting yang mendukung usaha. Dari hasil survei menunjukkan bahwa hanya sekitar $25 \%$ dari total sampel yang mengatakan bahwa kualitas sarana dan prasarana sangat baik, sedangkan $62,5 \%$ mengatakan cukup baik. Sedangkan 8\% pengusaha mengatakan sarana dan prasarana kurang baik. Ini menunjukkan bahwa sarana baru merupakan fakor yang mampu mendukung iklim usaha dalam arti minimalis, belum mampu menjadi daya dukung yang optimal.

Adapun fasilitas fisik yang sangat diperlukan oleh sebagian besar pegusaha adalah lahan usaha dan bangunan usaha untuk meningkatkan kegiatan usaha mereka. Fasilitas dari Pemerintah Kota Magelang dan Pemerintah Provinsi Jawa Tengah yang berupa promosi atau pameran untuk pemasaran langsung. Pemberian bantuan dana sebagai stimulasi usaha. Pemberian bantuan peralatan usaha secara kelompok. Kemudahan akses pasar dan pemberian pelatihan dibidang pengolahan, pengemasan, pemasaran.

Hasil dari wawancara didapatkan sebagian besar pengusaha mengatakan bahwa tingkat bunga perbankan mahal. Mereka berharap ada kebijakan dari pemerintah untuk memberikan subsidi tingkat bunga sehingga tidak membebani mereka. Dilihat dari persepsi mereka menunjukkan bahawa cost of capital masih mahal. Ini mendukung adanya high cost economy di Kota Magelang.

Biaya Operasional Usaha dapat diketahui dari beban biaya operasional usaha yang harus dikeluarkan, maka porsi yang terbesar ada pada mahalnya bahan baku yang mencapai 67,5 \%, sedangkan tenaga kerja 7,5\% dan bahan bakar $25 \%$, hal ini menunjukkan bahwa harga bahan baku makanan olahan cepat berubah terutama harga minyak goreng, tepung terigu dan telur. Oleh karena itu para pengusaha meminta bantuan kepada Pemerintah agar dapat menjaga kestabilan harga di pasar sehingga usaha rumah tangga tidak mengalami kebangkrutan.

Kemudahan mencari kredit usaha hasil wawancara yang dilakukan bahwa sekitar $60 \%$ pengusaha menyatakan tingkat bunga perbankan masih tinggi atau mahal, rendahnya plofond 7,5. Jangka waktu pendek $10 \%$, proses pengajuan cepat 5 $\%$ dan administrasi lainnya dan antrian 17,5\%. bahkan pencari kredit harus mempunyai agunan sertifikat tanah sebagai agunan pinjaman baik di BRI maupun bank yang lain. Waktu pengembalian pinjaman sekitar 2 sampai 5 tahun.

Berdasarkan uji korelasi bahwa variable independen promosi sebesar 0,538, variable pelatihan sebesar 0,590 dan variable bantuan alat sebesar 0,556 hal ini menunjukkan secara parsial ada hubungan positip antara variable independen (promosi, pelatihan dan bantuan alat) terhadap variable dependent produktivitas kerja. Pengetahuan yang dimiliki tenaga kerja terbatas, skill \& SDM belum sesuai dengan tujuan pengusaha, sering bolos kerja, malas, ongkos kerja borongan, kinerja menurun dan 
disiplin kurang, mencari pengganti tenaga kerja yang siap pakai sulit didapatkan. Tingkat pemanfaatan perkembangan teknologi masih kurang, baik dalam hal pahamnya kurang, daya belinya rendah dan penggunaannya mengalami kesulitan.

\section{Sarana dan prasarana UKM}

Di Kota Magelang meliputi mixer, oven, mesin pres, mesin penepung dan pemarut, kompor gas, wajan penggoreng, mesin packing, masih kurang baik dari segi jenis, jumlah dan tingkat kemutakiran alat. Teknologi masih bersifat tradisional dalam arti proses pengolahan menggunakan tungku, kayu bakar dan alat seadanya. Sumber daya manusia sebagai manajer masih langka dan tenaga kerja trampil dan terdidik masih kurang, motivasi kerja bersifat sambilan dari pada menganggur paling tidak bisa membantu suami dalam mencari nafkah.

\section{Promosi}

Promosi adalah komunikasi informasi antara penjual dan calon pembeli atau pihak-pihak lain dalam saluran untuk mempengaruhi sikap dan perilaku konsumen. Usaha untuk mengenalkan produk kepada pasar yaitu dilakukan strategi promosi. Konsep yang dipakai untuk mengenalkan produk yaitu promotion mix kegiatan-kegiatan yang mengkombinasikan keunggulan produk dan membujuk konsumen untuk membeli. Usaha yang perlu dilakukan adalah melalui promosi sebagai rangkaian rencana pemasaran secara keseluruhan. Strategi ini pada dasarnya merupakan proses komunikasi yang ditujukan untuk mempengaruhi perilaku konsumen kearah pengambilan keputusan yang positif dalam pembelian produk. Bentuk kegiatan promosi ini dilakukan oleh FEDEP memfasilitasi biaya sewa tempat pameran dan persiapan pameran. Adapun tempat promosi di Mall Paragon, PRPP Semarang, alun-alun Kota Magelang yang kegiatan dikaitkan dengan hari hari ulang tahun Kota Magelang, hari ulang tahun provinsi dan harihari besar lainnya.

\section{Pelatihan}

Pelatihan adalah suatu proses dimana orangorang mencapai kemampuan tertentu untuk membantu mencapai tujuan organisasi. pelatihan biasanya dilakukan dengan kurikulum yang disesuaikan dengan kebutuhan kebutuhan, diberikan dalam waktu yang relatif pendek, untuk membekali seseorang dengan keterampilan kerja. Institusi penyelenggara pelatihan Satuan Kerja Perangkat Daerah yaitu Dinas Perdagangan dan Perindustrian Kota Magelang maupun Provinsi Jawa Tengah. Adapun materi pelatihan disesuaikan dengan pratik kerja, cara penyampaian materi dari pelatih sesuai dengan kemampuan peserta, kemampuan pelatih dalam menyampaikan materi sudah teruji sebagai motivator lapangan, penyampaian materi dengan metode simulasi dan pratik sesuai dengan teknologi yang dikuasai peserta. Adapun tanggapan dari para pengusaha dalam wawancara para pengusaha merasa mendapatkan tambahan materi tentang pengemasan produk, cara menjaga sikap perilaku pemasaran, menjalin hubungan yang harmonis dengan para pelanggan, menjamin kualitas dan kuntinuitas produk.

\section{Bantuan Alat}

Wujud bantuan alat dan mesin didistribusikan sampai kepada peserta, penyerahan bantuan kepada klaster menjadi tanggung jawab ketua kelompok, bantuan alat dan mesin harus dalam kondisi baik, terakit sempurna, sudah di-running test (diuji coba dengan menghidupkan mesinnya) dan dilengkapi pedoman teknis bantuan alat, dengan petunjuk operasional/manual penggunaan dan perawatan. Tanggapan para pengusaha bahwa proposal permohonan bantuan peralatan agak mengalami keterlambatan sehingga target peningkatan produksinya mengalami hambatan, hal ini disebabkan sistem panganggaran dan keterbatasan anggaran dari SKPD yang bersangkutan. Di samping itu kendala di lapangan yang sering dialami pengusaha spesifikasi alat kurang sesuai dengan kebutuhan pengusaha.

\section{Produktivitas}

Produktivitas mengandung sebuah pengertian perbandingan antara hasil yang dicapai dengan peran serta tenaga kerja persatuan waktu. Pengertian ini menunjukkan bahwa ada kaitan antara hasil kerja dengan waktu yang dibutuhkan untuk menghasilkan produk dari seorang tenaga kerja. Tanggapan para pengusaha bahwa menyatakan ada peningkatan produktivitas kerja sesudah mendapatkan pelatihan, mendapatan bantuan alat dan fasilitasi pameran atau promosi. Keadaan ini dapat dibuktikan meningkatnya motivasi kerja, semakin efisien waktu dan bahan yang digunakan dalam proses produksi serta adanya peningkatan ketrampilan tenaga kerja.

\section{Analisis SPSS 16}

Hasil pengolahan data diperoleh $\mathrm{R}$ sebesar 0,757 hal ini menunjukkan bahwa ada hubungan yang sangat kuat antara variable promosi, pelatihan dan bantuan alat terhadap peningkatan produtivitas kerja. Sedangkan hasil penghitungan $\mathrm{R}^{2}$ ( $\mathrm{R}$ Square) diperoleh angka $\mathrm{R}^{2}$ sebesar 0,573 atau (573\%). Hal ini menunjukkan bahwa prosentase sumbangan pengaruh variable independen (promosi, pelatihan dan bantuan alat) terhadap variable dependen (produktivtas kerja) sebesar 573\%. Atau variasi variable independen yang digunakan dalam model (promosi, pelatihan dan bantuan alat) mampu menjelaskan oleh variasi lain yang tidak dimasukkan dalam model penelitian ini. Ho ditolak, $\mathrm{H}$ alf diterima artinya secara parsial ada pengaruh signifikan antara promosi, pelatihan dan bantuan alat terhadap produktivitas kerja. 


\section{SIMPULAN}

Pertama, bantuan pembangunan prasarana, Komponen penting pemberdayaan UKM adalah pembangunan prasarana produksi dan pemasaran. Tersedianya prasarana pemasaran dan atau transportasi dari lokasi produksi ke pasar, akan mengurangi rantai pemasaran dan akan meningkatkan penerimaan pengusaha kecil, dan pengusaha menengah.

Kedua, pengembangan skala usaha, Pemberdayaan ekonomi pada masyarakat dilakukan melalui kelompok oleh sebab itu akumulasi kapital harus dilakukan bersama-sama dalam wadah kelompok atau usaha bersama. Melalui kelompok, mereka dapat membangun kekuatan untuk ikut menentukan distribusi. Pengelompokan atau pengorganisasian ekonomi diarahkan pada kemudahan untuk memperoleh akses modal ke lembaga keuangan yang telah ada, dan untuk membangun skala usaha yang ekonomis. Aspek kelembagaan yang lain adalah dalam hal kemitraan antar skala usaha dan jenis usaha, pasar barang, dan pasar input produksi. Aspek kelembagaan ini penting untuk ditangani dalam rangka pemberdayaan ekonomi masyarakat.

Ketiga, pengembangan jaringan usaha, Pemasaran dan kemitraan usaha dan upaya mengembangkan jaringan usaha ini dapat dilakukan dengan berbagai macam pola jaringan misalnya dalam bentuk jaringan sub kontrak maupun pengembangan klaster. Pola jaringan usaha melalui sub kontrak dapat dijadikan sebagai alternatif bagi eksistensi UKM di Kota Magelang. Sedangkan pola pengembangan jaringan melalui pendekatan klaster, diharapkan menghasilkan produk oleh produsen yang berada di dalam klaster bisnis sehingga mempunyai peluang untuk menjadi produk yang mempunyai keunggulan kompetitif dan dapat bersaing di pasar.

Keempat, pengembangan Sumber Daya Manusia , Sumber daya manusia merupakan faktor penting bagi setiap usaha termasuk juga di sektor usaha kecil. Keberhasilan industri skala kecil untuk menembus pasar atau menghadapi produk-produk impor di pasar domestik ditentukan oleh kemampuan pelaku-pelaku dalam industri kecil tersebut untuk mengembangkan produk-produk usahanya sehingga tetap dapat eksis. Selain itu, salah satu bentuk pengembangan sumber daya manusia di sektor UKM adalah Pendampingan.

Kelima, peningkatan akses teknologi Penguasaan teknologi merupakan salah satu faktor penting bagi pengembangan Usaha Kecil Menengah. Keberhasilan usaha kecil menengah ditentukan oleh kemampuan akan penguasaan teknologi.

Keenam, ada hubungan yang sangat kuat antara variable promosi, pelatihan dan bantuan alat terhadap peningkatan produtivitas kerja. Sedangkan hasil penghitungan $\mathrm{R}^{2}$ ( $\mathrm{R}$ Square) diperoleh angka $\mathrm{R}^{2}$ sebesar 0,573 atau (573\%). Ada sumbangan pengaruh variable independent (promosi, pelatihan dan bantuan alat) terhadap variable dependen (Produktivtas kerja) sebesar 573\%. Atau variasi variable independen yang digunakan dalam model (promosi, pelatihan dan bantuan alat) mampu menjelaskan oleh variasi lain yang tidak dimasukkan dalam model penelitian ini. Akhirnya Ho ditolak, $\mathrm{H}$ alf diterima artinya secara parsial ada pengaruh signifikan antara promosi, pelatihan dan bantuan alat terhadap produktivitas kerja.

\section{Saran}

Pertama, pemerintah perlu memberikan subsidi bantuan peningkatan fasilitas UKM pengolahan makanan ringan di Kota Magelang baik lokasi secra berkelompok, peralatan pengolahan meliputi: mixer, oven, mesin pres,mesin penepung dan pemarut, kompor gas, wajan, mesin packing dan kemudahan penambahan modal kerja serta pemasaran. Pemerintah perlu meningkatkan pelatihan bagi Usaha Kecil Menengah baik dalam aspek kewiraswastaan, administrasi dan pengetahuan serta ketrampilan dalam pengembangan usaha. Pemerintah lebih memperhatikan adanya regulasi untuk menyediakan area-area yang diperuntukkan bagi sentra-sentra pengembangan usaha (spasial) sehingga akan menjamin kelangsungan usaha. Kebijakan tata ruang merupakan faktor yang sangat penting. Hal ini disebabkan usaha-usha kecil yang ada di Kota Magelang berbaur dengan perumahan untuk kediaman tempat tinggal.

Kedua, peningkatan kualitas SDM dilakukan melalui berbagai cara seperti pendidikan dan pelatihan, seminar dan lokakarya, on the job training, pemagangan dan kerja sama usaha. Selain itu, juga perlu diberi kesempatan untuk menerapkan hasil pelatihan di lapangan untuk mempraktekkan teori melalui pengembangan kemitraan rintisan.

Ketiga, pendampingan UKM perlu dan penting. Tugas utama pendamping ini memfasilitasi proses belajar atau refleksi dan menjadi mediator untuk penguatan kemitraan baik antara usaha mikro, usaha kecil, maupun usaha menengah dengan usaha besar.

Keempat, strategi yang perlu dilakukan dalam peningkatan akses teknologi bagi pengembangan usaha kecil menengah adalah memotivasi berbagai lembaga penelitian teknologi yang lebih berorientasi untuk peningkatan teknologi sesuai kebutuhan UKM, pengembangan pusat inovasi desain sesuai dengan kebutuhan pasar, pengembangan pusat penyuluhan dan difusi teknologi yang lebih tersebar ke lokasilokasi Usaha Kecil Menengah dan peningkatan kerjasama antara asosiasi-asosiasi UKM dengan perguruan Tinggi atau pusat-pusat penelitian untuk pengembangan teknologi UKM. 


\section{DAFTAR PUSTAKA}

Dunn, William N. 1994. Pengantar Analisis Kebijakan Publik. Yogyakarta: Gajah Mada University Press.

Dye, Thomas R. 1992. Understanding Publik Polic Policy.New Jersey: Engewood Cliffs.

Edwards III George C. 1980. Implementing Public Policy. Washington: Conggressional Quartely Inc.

Gauthama, Margaret P. 1999. Penerapan Teknologi Tepat Guna pada Pengrajin Gerabah di Desa Banyumelek, Lombok Barat. dalam Alkadri Muchdie, dan Suhandoyo (penyunting). Jakarta: Tiga Pilar Pengembangan Wilayah Sumber Alma, Sumber Daya Manusia, Teknologi.

Hadi, AP. 1999. Strategi Komunikasi dalam Mengatipasi Kegagalan Penerapan Teknologi oleh Petani Komunitas. Journal of Rural Studies, 2 (2).

Tjokrowinoto, Moeljarto. 1996. Pembangunan Dilema dan Tantangan. Yogyakarta: Tiara Wacana.

Nonaka, Ikujiro \& Takeuchi, Hirotaka. 1995. The Knowledge-Creating Company: How Japanese Companies Create the Dynamics of Innovation. Oxford: Oxford University Press.

Handari, Nawawi. 1990. Administrasi Personel untuk Peningkatan produktivitas Kerja. Jakarta: Haji Masagung.

Ravianto, J. 1986. Pengukuran Produktivitas. Yogyakarta: Kanisius. 
